\title{
The Effectiveness of Crocodile Oil Extract Ointment on the Treatment of Burns in Mice (Mus musculus)
}

\author{
Sarce Makaba ${ }^{1}$, Rosmin M. Tingginehe ${ }^{1}$, Yacob Ruru ${ }^{2}$ \\ ${ }^{1}$ Faculty of Public Health, Cenderawasih University, Jayapura, Papua, Indonesia, ${ }^{2}$ Department of Statistics, \\ Faculty of Mathematics and Natural Sciences, Cenderawasih University, Jayapura, Papua, Indonesia
}

\begin{abstract}
The purpose of this study was to determine the effectiveness of the crocodile oil extract ointment in the treatment of burns in mice (Mus musculus). The research found that the ointment of crocodile oil extract has an effect in the healing of burns in mice (Mus musculus), with the best concentration of $30 \%$ of the crocodile oil extract ointment dose. Moreover, the ointment met the standard on the basis of organoleptic and homogeneity tests. The ointment of crocodile oil extract with concentrations of $30 \%$ and $50 \%$ has the healing activity degree II-A burns in mice (Mus musculus). The best percentage of reductions in average burns in mice was the ointment with a concentration of $30 \%$. Further study needs to be done in the healing of wound in human skin.
\end{abstract}

Keywords: Burn, crocodile oil extract, effectiveness, ointment.

\section{Introduction}

Burns is one of the most common injuries in accidents and continues to be a global public health problem. ${ }^{1}$ Burn injuries can lead to complications such as long-term disability, prolonged hospitalization, loss of body limbs and even death. ${ }^{2}$ Wound repair is a process that follows skin injury, which is initiated by an inflammatory reaction and the cells below the dermis begin to increase the production of collagen. The epithelial tissue is then regenerated. ${ }^{3}$ Although many advances have been made in our understanding and in the care of burn injuries, modern medicine still has a challenge to heal burn injuries. ${ }^{1}$

Traditional medicine has existed since human civilization and has been growing for thousands of years with the combination of new technology in the search for good drugs. ${ }^{4,5}$ This is important for public health, based on the experience and knowledge that has been collected to date. Humans have used medicines for alleviating and

\section{Corresponding Author:}

\section{Sarce Makaba}

Faculty of Public Health, Cenderawasih University, Jayapura, Papua, Indonesia

e-mail: sarcemakaba20@gmail.com treating diseases with natural products such as plants, animals, microorganisms and marine organisms. ${ }^{6,7}$

Traditional medicine is one of the nation's cultural heritages, which is very valuable for the preservation of traditional medicine for public health. The development of the use of natural ingredients as a traditional medicine is now more desirable, as it is relatively easy to obtain. This is generally derived from a wide variety of plants, animals and minerals. Natural materials such as plants, animals and mixtures of these materials may be used as traditional medicines. They contain a variety of compounds that can affect the living cells of the organ. Wound injury healing process is effectively promoted through the use of traditional remedies, mainly based on plant and animal sources. ${ }^{1}$ In addition; natural ingredients have minimal side effects. One of the natural ingredients used as a traditional medicine other than plants is derived from animals such as the use of crocodile oil for treatment.

Siamese crocodile (Crocodylus siamensis) is one of the freshwater crocodile species that was originally distributed throughout Southeast Asia. ${ }^{8}$ Crocodile oil has been shown to be very effective in the treatment of diseases, ranging from skin conditions to cancer, and has been used by traditional practitioners for centuries. ${ }^{9}$ In Africa, crocodile oil is used to treat skin rashes and 
promote wound healing. ${ }^{9}$ Crocodile oil has been used by local communities in Papua to treat various diseases, both as an internal medicine and as an external medicine, namely treatment of skin diseases such as skin burns or for other reasons.

Burns have recently increased to be a major cause of morbidity and mortality in low-and middle-income countries. Burns accounts for $1 \%$ of the global disease burden ${ }^{10}$, causes more than 7.1 million injuries and more than 265,000 deaths worldwide each year. ${ }^{11}$ The latest data on burns in Indonesia was obtained from the Ministry of Health (published in 2019), which showed that the proportion of burns in Indonesia was 1.3. In addition, the proportion of burn injuries in Papua Province was 2.1, which is higher than in the national. ${ }^{12}$

Antibiotics and anti-septics are widely used in the treatment of burns, but besides having advantages, they also have disadvantages. Some types of bacteria found in burns are resistant to some antibiotics. ${ }^{13,14}$ In addition, anti-septic may also cause irritation to sensitive victims, discoloration of the skin, and may cause skin scarring. ${ }^{15}$ On the basis of these reasons, it is necessary to find other alternatives for the treatment of burns, one of which is by using natural compounds derived from plants and animals. ${ }^{16}$ Traditional medicine, derived from animals used by humans to treat burns, is crocodile oil. Crocodile oil contents such as fat, vitamin E, vitamin A, linoleic acid, sapogen and antiseptic terpine are useful for the treatment and softening of the skin. It is effective in treating conditions such as eczema, psoriasis and chapped lips. Crocodile oil contains fatty acids such as 3, 6 and 9 omega. These three ingredients are effective against inflammation, helping to reduce the appearance of redness, especially in skin conditions that are sensitive and easily reddened. Oleic acid is another ingredient in crocodile oil. This content is very important to help regenerate cells in the treatment of wounds and irritations. According to Khaitami, crocodile oil can significantly accelerate the healing of wounds and irritations and reduce the appearance of scars. ${ }^{17} \mathrm{In}$ some components, crocodile oil is similar to coconut oil in terms of skin protection. However, crocodile oil contains fatty acids with a higher level of truncation than coconut oil, i.e. omega 3, 6 and 9 . This substance is very important to maintain a healthy skin layer. Crocodile oil has moisturizing properties like other oils. The function is to protect the skin biologically from dryness. The use of crocodile oil to treat burns by the public is still very traditional. Moreover, it has not yet been formulated in any form of any kind. The authors are therefore interested in developing the extract of crocodile oil into a pharmaceutical preparation to increase its use. One drug preparation that is easy to use is the ointment. Ointment was chosen because it is the most appropriate pharmaceutical preparation for medicinal purposes for the skin due to prolonged contact between the drug and the skin. Ointment is a semi-solid preparation in the form of a soft mass which is easily applied and used as an external medicine. The ingredients of the medicine must be dissolved and dispersed in an appropriate ointment base. The use of natural medicines by the community is still limited, both in terms of dose determination and how to concoct. In this study, the authors provide information on concentrations that have an effect on easier-to-use skin and drug dosage forms, namely by formulating ointment preparations.

\section{Material and Method}

This study is an experimental laboratory with a completely randomized design (CRD) analysis conducted at the Laboratory of Bio-Pharmacy, Hasanuddin University, Makassar, in April 2019. The study has been approved by the Ethic Committee of the Hasanuddin University, Makassar, Indonesia, with document no. UH20010056. The work was conducted in vivo on 25 burn-induced mice which were divided into 5 treatment groups namely Group 1 (positive control) using Bioplacenton, Group 2 (negative control) using Vaseline album, Group 3, Group 4, and Group 5 using crocodile oil extract with a concentration of $15 \%, 30 \%$ and $50 \%$, respectively. Organoleptic and homogeneity tests were performed for the quality of the ointment. Examination of the effectiveness of the ointments as a medicine for the healing of burns was done in mice (Mus musculus).

Animals: Healthy 25 male albino Wistar rats (Mus musculus) about the age of 4-5 weeks, and body weight range $(26.6 \pm 6.4)$ grams were obtained from the Laboratory Animal in Maros Regency, South Sulawesi, Indonesia. The animals were housed in stainless steel cages with the area of $(30 \mathrm{~cm} \times 50 \mathrm{~cm} \times 15 \mathrm{~cm})$, and were kept under standard conditions 12 hours light, 12 hours dark at $22 \pm 2^{\circ} \mathrm{C}$ and $50-60 \%$ relative humidity. The animals were given standard food about 300 grams per day and water. Mice are laboratory animals commonly used as a research model before being treated in humans. 
Crocodile Oil Extraction: Siamese crocodile (Crocodylus siamensis) oil was derived from crocodiles in the Mamberamo River, Mamberamo District, Papua Province, Indonesia. It was taken directly by crocodile hunters from the river. Oil was extracted using nonchemical method that are stream rendering. First, the crocodile meat was cut into small pieces, about 3-6 $\mathrm{cm}$ in diameter, then ground. It was then flowing at a temperature of $90^{\circ} \mathrm{C}$ for about 45 minutes. The cooked fat was wrapped in cloth and pressed onto the machine. The crude oil was divided into liquid fractions and the oil was centrifuged.

Making Ointments: The following is the formulation of a crocodile oil ointment extract with different concentrations for the treatment groups: 1) Ointment of crocodile oil extract with a concentration of $15 \%$, R/Ointmen base 12.75 grams, Crocodile oil extract 2.25 grams, Adesplanae 15 gram; 2) Crocodile oil ointment extract with a concentration of $30 \%, \mathrm{R} /$ Ointment base 10.5 grams, Crocodile oil extract 4.5 grams, Adesplanae 15 grams; 3) Crocodile oil extract ointment with a concentration of $50 \%$, R/Ointment base 7.5 grams, 7.5 grams crocodile oil extract, Adesplanae 15 grams. How to make it: For each group, weigh all the ingredients needed. Cetyl alcohol and liquid paraffin are melted down, using a porcelain cup on a water bath at a temperature of around $70^{\circ} \mathrm{C}-75^{\circ} \mathrm{C}$, while stirring continuously using a stirring rod until an ointment mass is obtained. The extract of crocodile oil was put into mortar, and then added the ointment base little by little while being crushed until homogeneous. The ointment is placed in a container and stored tightly in a place protected from light.

Organoleptic Test: Observations made in this test are the shape, odor and color of the preparation. The quality parameters of a good ointment are a semi-solid form, the ointment smells typical of the extract used and is colored like an extract. ${ }^{18}$

Homogeneity Test: Homogeneity test of preparations was carried out by observing the results of applying ointment on a glass plate. Homogeneous ointment is characterized by the absence of lumps in the basting result, a flat structure and has a uniform color from the starting point of the basting to the finishing point. The ointment tested was taken from three places namely the top, middle and bottom of the ointment container. ${ }^{19}$
Test the Effectiveness of Crocodile Oil Extract Ointment on Mice (Mus musculus): Testing the healing effect of burns is done using animal experiments of mice (Mus musculus). Mice were grouped into five groups, namely the positive control group (Bioplacenton $\left.{ }^{\circledR}\right)$, the negative control group (Vaseline base), the concentration of crocodile oil ointment extract 15 per cent, 30 per cent and 50 per cent. The mice were shaved on the back, then the skin was induced by a heat induction tool. The extent of the injury is measured after each group is treated with an ointment. Observation was carried out until signs of healing of wounds appeared. Wound healing is marked by the beginning of the edge of the wound that is bright red and bleeds easily, then changes from bright red to dark red for several days. Next, the cells begin to fill the wound area with new collagen to form a scab; this tissue grows from the edge of the wound to the wound bed, and then the wound contracts. Wound contractions are the result of myofibroblast action. Myofibroblast crosses the wound and pulls the edge of the wound to close the wound. Increased blood flow to damaged areas, early cell cleansing from foreign cell development is part of the healing process. The diameter of the wound is calculated according to the formula as shown in equation $1 .^{20}$

$$
d x=\frac{d x(1)+d x(2)+d x(3)+d x(4)}{4}
$$

Where:

$\mathrm{dx}$ is a the diameter of the burn of day $\mathrm{x}(\mathrm{mm})$

$d x(1), d x(2), d x(3)$, and $d x(4)$ are burn diameters measured from 4 different angels.

In addition, the percentage of wound healing can be calculated using the formula in equation $2:^{20}$

$$
P x=\left(\frac{d 1^{2}-d x^{2}}{d 1^{2}}\right) \times 100 \%
$$

Where:

Px : Percentage of treatment on day $x$ (percent)

$\mathrm{d} 1$ : The diameter of the wound on the first day

$\mathrm{dx}$ : The diameter of the wound on day $\mathrm{x}$

Statistical Analyses: The results are expressed as mean \pm standard deviation of the mean. A one-way ANOVA with LSD post hoc tests were used for multiple comparisons. A p $<0.05$ was considered statistically significant. 


\section{Findings:}

Organoleptic test: The test was performed to determine the shape, color and smell. The results show the four types of ointment (Table 1). The ointments have a semi-solid shape, white gray to light brown color, and the ointment smells typical of Vaselin used. They all indicate that the ointments are good.

Table 1. The result of an organoleptic test on the crocodile oil extract ointment.

\begin{tabular}{|c|l|l|l|l|}
\hline No & Type of the Ointment & Shape & Color & Smell \\
\hline 1 & Ointment base & Semi-solid & White gray & Typical ointment smell (Vaselin) \\
\hline 2 & Ointment of crocodile oil extract $(15 \%)$ & Semi-solid & White gray & Typical ointment smell (Vaselin) \\
\hline 3 & Ointment of crocodile oil extract $(30 \%)$ & Semi-solid & White brown & Typical ointment smell (Vaselin) \\
\hline 4 & Ointment of crocodile oil extract $(50 \%)$ & Semi-solid & Light brown & Typical ointment smell (Vaselin) \\
\hline
\end{tabular}

Source: Primary Data, 2019

Homogeneity Test: The test was done by taking the ointment from the top, the middle, and the bottom. The ointment is then applied to a piece of glass object. The results of the test can be found in Table 2. It has been shown that all experimental groups are homogeneous.

Table 2. The homogeneity test on the ointment of crocodile oil extract

\begin{tabular}{|c|l|c|}
\hline No & Type of the Ointment & Homogeneity \\
\hline 1 & Ointment base & Homogeneous \\
\hline 2 & $\begin{array}{l}\text { Ointment of crocodile oil } \\
\text { extract }(15 \%)\end{array}$ & Homogeneous \\
\hline 3 & $\begin{array}{l}\text { Ointment of crocodile oil } \\
\text { extract }(30 \%)\end{array}$ & Homogeneous \\
\hline 4 & $\begin{array}{l}\text { Ointment of crocodile oil } \\
\text { extract }(50 \%)\end{array}$ \\
\hline
\end{tabular}

Characteristics of mice based on age, and body weight: The experimental animals used in this study were mice (Mus musculus). They were divided into five treatment groups. Each group consisted of five species. Group 1 was a negative control group (Vaselin/placebo), group 2 was a positive control group (Bioplacenton), group 3 was a $15 \%$ concentration of crocodile oil extract, group 4 was a $30 \%$ concentration of crocodile oil extract and group 4 was a $50 \%$ concentration of crocodile oil extract. Characteristics of mice based on age and body weight in each treatment group as shown in Table 3 . It can be seen that the mice are 4-5 weeks old and have a body weight of about $(26.6 \pm 6.4)$ grams.

Table 3. The characteristics of mice based on age, and body weight

\begin{tabular}{|c|c|c|c|c|}
\hline No & Group & & Body weight (grams) & Age (weeks) \\
\hline \multirow{5}{*}{1} & \multirow{5}{*}{ Negative control (-) } & 1 & 22.6 & $4-5$ \\
\hline & & 2 & 30.1 & $4-5$ \\
\hline & & 3 & 32.6 & $4-5$ \\
\hline & & 4 & 28.7 & $4-5$ \\
\hline & & 5 & 39.1 & $4-5$ \\
\hline \multirow{5}{*}{2} & \multirow{5}{*}{ Positive control $(+)$} & 1 & 20.8 & $4-5$ \\
\hline & & 2 & 21.4 & $4-5$ \\
\hline & & 3 & 24.2 & $4-5$ \\
\hline & & 4 & 22.4 & $4-5$ \\
\hline & & 5 & 23.5 & $4-5$ \\
\hline
\end{tabular}




\begin{tabular}{|c|c|c|c|c|}
\hline No & Group & & Body weight (grams) & Age (weeks) \\
\hline \multirow{5}{*}{3} & \multirow{5}{*}{$\begin{array}{l}\text { Crocodile oil extracts ointment } \\
(15 \%)\end{array}$} & 1 & 22.6 & $4-5$ \\
\hline & & 2 & 40.6 & $4-5$ \\
\hline & & 3 & 37.8 & $4-5$ \\
\hline & & 4 & 36.3 & $4-5$ \\
\hline & & 5 & 35.4 & $4-5$ \\
\hline \multirow{5}{*}{4} & \multirow{5}{*}{$\begin{array}{l}\text { Crocodile oil extracts ointment } \\
(30 \%)\end{array}$} & 1 & 24.1 & $4-5$ \\
\hline & & 2 & 22.8 & $4-5$ \\
\hline & & 3 & 25.4 & $4-5$ \\
\hline & & 4 & 22.8 & $4-5$ \\
\hline & & 5 & 21.4 & $4-5$ \\
\hline \multirow{5}{*}{5} & \multirow{5}{*}{$\begin{array}{l}\text { Crocodile oil extracts ointment } \\
(50 \%)\end{array}$} & 1 & 24.7 & $4-5$ \\
\hline & & 2 & 21.9 & $4-5$ \\
\hline & & 3 & 21.7 & $4-5$ \\
\hline & & 4 & 20.8 & $4-5$ \\
\hline & & 5 & 21.9 & $4-5$ \\
\hline
\end{tabular}

Source: Primary Data, 2019

Examination of Healing Burns of Crocodile Oil Extract Ointment on Mice.

The measurement of reduction diameter of burn in mice: The results of measurements of the 14-day reduction in the diameter of burns in mice can be seen in Table 4. It was shown that: for the positive group, the reduction in burn diameter was approximately $(8.83 \pm 1.518) \mathrm{mm}$; for the negative group, the reduction in burn diameter was approximately $(11.99 \pm 2.754)$ $\mathrm{mm}$; for the formula 15 percent group, the reduction in burn diameter was approximately $(10.07 \pm 1.813) \mathrm{mm}$; for the formula 30 percent group, the reduction in burn diameter was approximately $(12.61 \pm 2.228) \mathrm{mm}$; and for the formula 50 percent group, the reduction in burn diameter was approximately $(12.95 \pm 2.571) \mathrm{mm}$.

Table 4. The average diameter of burns in mice.

\begin{tabular}{|c|l|c|c|c|}
\hline No & Group & $\begin{array}{c}\text { Average Diameter of } \\
\text { Initial Burn (mm) (Pre) }\end{array}$ & $\begin{array}{c}\text { Average Diameter of } \\
\text { Final Burn (mm) (Post) }\end{array}$ & $\begin{array}{c}\text { Reduction in Diameter } \\
\text { of Burns (mm) }\end{array}$ \\
\hline 1 & Positive control (+) & $18.98 \pm 0.558$ & $10.14 \pm 1.695$ & $8.83 \pm 1.518$ \\
\hline 2 & Negative control (-) & $18.38 \pm 1.897$ & $6.38 \pm 3.249$ & $11.99 \pm 2.754$ \\
\hline 3 & Crocodile oil extracts ointment (15\%) & $18.15 \pm 0.950$ & $8.07 \pm 1.863$ & $10.07 \pm 1.813$ \\
\hline 4 & Crocodile oil extracts ointment (30\%) & $19.10 \pm 1.178$ & $6.48 \pm 1.612$ & $12.61 \pm 2.228$ \\
\hline 5 & Crocodile oil extracts ointment (50\%) & $19.99 \pm 0.527$ & $7.03 \pm 2.554$ & $12.95 \pm 2.571$ \\
\hline \multicolumn{2}{r|}{ P-value of ANOVAs Test } & 0.06 & 0.034 & 0.009 \\
\hline
\end{tabular}

Source: Primary Data, 2019

Statistical test results using ANOVA for the reduction in burn diameter in mice were obtained by $\mathrm{p}$-value $=0.009(\mathrm{p}<0.05)$, which means that there was a significant difference in the reduction in burn diameter in the five treatment groups. In addition, the analysis continued with further tests using the LSD (Least Significant Difference) Pos Hoc test and found that the formula $30 \%$ and the formula $50 \%$ were the best ones to reduce burns in mice in diameter. 
The Post-Hoc test: This test was performed to determine the significant difference between the groups in the average reduction of the wound diameter. The result has been shown in Table 5. The table shows that: 1) There was a significant difference in mean wound diameter reduction between the positive $(+)$ control group and the negative $(-)$ control group $(\mathrm{d}=3.163$, $\mathrm{p}=0.015) ; 2$ ) There was a significant difference in mean wound diameter reduction between the positive $(+)$ control group and the $30 \%$ crocodile oil group $(\mathrm{d}=3.785$, $\mathrm{p}=0.007) ; 3$ ) There was a significant difference in mean wound diameter reduction between the positive $(+)$ control group and the $50 \%$ crocodile oil group $(\mathrm{d}=4.122$, $\mathrm{p}=0.002)$; 4) There was a significant difference between the $15 \%$ concentration of the crocodile oil group and the
$30 \%$ concentration of the crocodile oil group $(\mathrm{d}=2.539$, $\mathrm{p}=0.005$ ) in the mean reduction of the wound diameter; 5) There was a significant difference between the $15 \%$ concentration of the crocodile oil group and the 50\% concentration of the crocodile oil group $(\mathrm{d}=2.876$, $\mathrm{p}=0.026$ ) in the mean reduction of the wound diameter; and 6) Although there is a difference in the mean reduction of the wound diameter between the positive $(+)$ control group and the formula 15 per cent; the negative (-) control group and the formula $15 \%$; the negative (-) control group and the formula $30 \%$; the negative (-) control group and the formula $50 \%$; and the difference between the formula $30 \%$ and the formula $50 \%$; however, the difference was not statistically significant.

Table 5. The Post-Hoc test results (LSD) of the diameter reduction of burns in mice.

\begin{tabular}{|l|c|c|c|c|c|}
\hline N=31 Average difference (P-value) & Control (+) & Control (-) & Formula 15\% & Formula 30\% & Formula 50\% \\
\hline Control (+) & - & $3.163(0.015)^{*}$ & $1.245(0.297) \mathrm{ns}$ & $3.785(0.007)^{*}$ & $4.122(0.002)^{*}$ \\
\hline Control (-) & $3.163(0.015)^{*}$ & - & $1.918(0.127) \mathrm{ns}$ & $0.621(0.643) \mathrm{ns}$ & $0.958(0.445) \mathrm{ns}$ \\
\hline Formula 15\% & $1.245(0.297) \mathrm{ns}$ & $1.918(0.127) \mathrm{ns}$ & - & $2.539(0.05)^{*}$ & $2.876(0.026)^{*}$ \\
\hline Formula 30\% & $3.785(0.007)^{*}$ & $0.621(0.643) \mathrm{ns}$ & $2.539(0.05)^{*}$ & - & $0.337(0.801) \mathrm{ns}$ \\
\hline Formula 50\% & $4.122(0.002)^{*}$ & $0.958(0.445) \mathrm{ns}$ & $2.876(0.026)^{*}$ & $0.337(0.801) \mathrm{ns}$ & - \\
\hline
\end{tabular}

*Significant; ns=not significant

Percent reduction of average burn diameter in mice:

Table 6. The percentage reduction in the average diameter of burn in mice.

\begin{tabular}{|c|l|c|c|c|}
\hline No & Group & $\begin{array}{c}\text { Average Diameter of } \\
\text { Initial Burn (mm) (Pre) }\end{array}$ & $\begin{array}{c}\text { Average Diameter of } \\
\text { Final Burn (mm) (Post) }\end{array}$ & $\begin{array}{c}\text { Percentage of Reduction } \\
\text { in Average Diameter of } \\
\text { Burns (\%) }\end{array}$ \\
\hline 1 & Control (+) & $18.98 \pm 0.558$ & $10.14 \pm 1.695$ & 46.52 \\
\hline & Control (-) & $18.38 \pm 1.897$ & $6.38 \pm 3.249$ & 65.23 \\
\hline 2 & Ointment of crocodile oil extract (15\%) & $18.15 \pm 0.950$ & $8.07 \pm 1.863$ & 55.48 \\
\hline 3 & Ointment of crocodile oil extract (30\%) & $19.10 \pm 1.178$ & $6.48 \pm 1.612$ & 66.02 \\
\hline 4 & Ointment of crocodile oil extract (50\%) & $19.99 \pm 0.527$ & $7.03 \pm 2.554$ & 64.78 \\
\hline
\end{tabular}

Source: Primary Data, 2019

The percentage reduction of average burn in mice after treatment until day 14 can be seen in Table 6. It was shown that: for the positive group, the percentage reduction of the average burn diameter was approximately $46,52 \%$; for the negative group, the percentage reduction of the average burn diameter was approximately $65,23 \%$; for the formula $15 \%$ group, the percentage reduction of the average burn diameter was approximately $55,48 \%$; for the formula $30 \%$ group, the percentage reduction of the average burn diameter was approximately $66.02 \%$; and for the formula $50 \%$ group, the percentage reduction of the average burn diameter was approximately $64.78 \%$. The formula $30 \%$ is best suited to the reduction of average mice burn diameter $(66.02 \%)$. 


\section{Discussion}

Crocodile oil has been used by the public to cure various skin conditions, while others are used as cosmetics to smooth the skin. Crocodile oil is the same as human skin oil. They differ only in terms of the percentage of available material. Because of its composition, which is identical to human skin oil, crocodile oil is rarely allergic when applied to human skin. This will also be a very suitable and safe product to use. ${ }^{21}$ Crocodile oil and items containing crocodile oil which are currently on the market are used for the following purposes: ${ }^{21} 1$ ) Therapy for dermatitis, 2) Treatment of bruises, pimples, rash bumps, bed sores, hemorrhoids and anal fissures, 3) Reduces discomfort and inflammation in arthritis, 4) Treatment for loss of color and pigmentation of brown spots such as skin, spots and darkening of menopause, 5) Treatment of dry, scaly, itchy and flaky skin (such as aging), rash, athlete's foot, athlete's scratching, and scalp irritation.

There have been many positive claims in the use of products containing crocodile oil. Those include fading streaks, pimples, zit signs, dark lines, wrinkles and lines of laughter. This involves the absence of irregular dark shades, blurred shadows, sunspots and other color shifts. This helps prevent discoloration from developing, making the skin smoother, lighter and more appealing. It also manages rash and dryness. ${ }^{21}$

Burns are the most common incidents encountered by the community, particularly in households. This is indeed very critical that medication supplies rapidly resolve the healing of burns and avoid things from getting worse. The most severe burns are second-grade burns.

Pharmaceutical preparations were made in the form of ointments using the base of Vaseline album in this study. The aim of the preparation in the form of an ointment is to prolong the time of contact with the surface of the burn skin on the mice. In this type, the active ingredient in the extract of crocodile oil is capable of providing optimum stimulation for the healing process of burns on the surface of the mice's skin. The longer the drug is in contact with the surface of the skin, the higher the strength of the drug absorbed by the surface of the skin for the healing process.

The formulation of the ointment consists of 3 types of concentrations in order to see its efficacy in the process of treating the burns in mice. In addition, the organometric and homogeneity tests have been performed as a quality control test for the products involved in the healing process of mice burns. The color of the crocodile oil extract ointment is the same as the color of the crocodile oil extract, which is white to light brown chocolate. Observation of ointment preparations reveals that the ointment has a distinct odor of ointment from extracts of crocodile oil. Supply of ointment extracts of crocodile oil at all concentrations has a strong homogeneity, because there are no lumps that minimize its homogeneity.

The findings of the study showed that the ointment extract of crocodile oil has efficacy in the healing of mice burns. That can be seen from the calculation of average burn diameter in mice from the first day of treatment to the $14^{\text {th }}$ day with a substantial decrease in average burn diameter (ANOVA test, $\mathrm{p}<0.05$ ). Based on the LSD Pos Hoc test, it was found that the $30 \%$ concentration of crocodile oil extract ointment had a higher percentage reduction in the average burn diameter of the mice $(66.02 \%)$.

\section{Conclusion}

In conclusion, the ointment of crocodile oil extract has an effect of the healing of burns in mice (Mus musculus). In addition, the safest treatment for treating burns in mice is the ointment composed of $30 \%$ of the crocodile oil extract. Further research needs to be done on the magnitude of potential healing burns in human skin.

\section{Conflict of Interest: Nil}

Source of Funding: Cenderawasih University

Ethical Clearance: The Ethic Committee of the Hasanuddin University, Makassar, Indonesia, with document no. UH20010056.

\section{References}

1. Li HL, Chen LP, Hu YH, Qin Y, Liang G, Xiong YX, Chen QX. Crocodile Oil Enhances Cutaneous Burn Wound Healing and Reduces Scar Formation in Rats. Academic Emergency Medicine 2012;19:265-273.

2. Upadhyay NK, Kumar R, Mandotra SK, Meena RN, Siddiqui MS, Sawhney RC, Gupta A. Safety and healing efficacy of Sea buckthorn (Hippophae rhamnoides L.) seed oil on burn wounds in rats. 
Food and Chemical Toxicology 2009;47:11461153.

3. Wilgus TA. Immune cells in the healing skin wound: influential players at each stage of repair. Pharmacological Research 2008;58:112-116.

4. Ngo LT, Okogun JI, Folk WR. $21^{\text {st }}$ Century natural product research and drug development and traditional medicines. Nat Prod Rep 2013;30:584592.

5. Zhu F, Ma XH, Qin C, Tao L, Liu X, Shi Z, et al. Drug discovery prospect from untapped species: Indication from approved natural product drugs. PLoS ONE 2012;7(7):1-9.

6. Shi QW, Li LG, Huo CH, Zhang ML, Wang YF. Study on natural medicinal chemistry and new drug development. Chin Tradit Herb Drugs 2010;41:1583-1589.

7. Fabricant DS, Farnsworth NR. The Value of Plants Used in Traditional Medicine for Drug Discovery. Environ Health Perpect 2001;109:69-75.

8. Kang JH, Zhang WQ, Song W, Shen DY, Li SS, Tian L, et al. Apoptosis mechanism of human cholangiocarcinoma cells induced by bile extract from crocodile. Appl Biochem Biotechnol 2012;166:942-951.

9. Buthelezi S, Southway C, Govinden U, Bodenstein $\mathrm{J}$, du Toit K. An investigation of the antimicrobial and anti-inflammatory activities of crocodile oil. Journal of Ethnopharmacology 2012;143:325-330.

10. Elsous A, Ouda M, Mohsen S, Al-Shaikh M, Mokayad S, Abo-Shaban N, et al. Epidemiology and outcomes of hospitalized burn patients in Gaza strip: a descriptive study. Ethiop J Health Sci 2016; 26:9-16.

11. WHO. WHO Health Estimates 2014 Summary Tables: Death and Global Burden of Disease. 2014.

12. Kementerian Kesehatan RI. Laporan Riset

Kesehatan Dasar 2018 Nasional. Jakarta. Balibangkes. 2019.

13. Lachiewicz AM, Hauck CG, Weber DJ, Cairns BA, and Duin DV. Bacterial Infections After Burn Injuries: Impact of Multidrug Resistance. Clinical Infectious Diseases 2017;65:2130-2136.

14. Sabzghabaee AM, Abedi D, Fazeli H, Javadi A, Jalali M, Maracy MR, et al. Antimicrobial resistance pattern of bacterial isolates from burn wounds in an Iranian University Hospital. Journal of Research in Pharmacy Practice 2012;1:30-33.

15. Lachapelle JM. A comparison of the irritant and allergenic properties of antiseptics. Eur J Dermatol 2014; 24(1):3-9.

16. Anggraini N, Atikah N, Hardani. Optimasi Dosis Sediaan Salep Ekstrak Daun Lamtoro (Laucaea glauca) yang Efektif Terhadap Penyembuhan Luka Bakar Pada Mencit (Mus musculus), Prosiding Seminar Nasional Kesehatan. 2018. ISBN 978602-50761-9-0.

17. Khaitami M. Ini dia khasiat rahasia minyak buaya. Available from: https://banjarmasin.tribunnews. com/2015/11/09/ini-dia-khasiat-rahasia-minyakbuaya. Accessed on: 16 April 2019.

18. Anief M. Farmasetika. Yogyakarta, Gajah Mada University Press. 2005.

19. Anonim. Farmakopeindonesia. Edisi 4. Departemenkesehatan RI: Jakarta. 1995.

20. Suratman, S A., Sumiwi, D., dan Gozali, G. Pengaruh Ekstrak Antanan dalam Bentuk Salep, Krim dan Jelly terhadap Penyembuhan Luka Bakar. Cermin Dunia Kedokteran 1996;108:31-36.

21. City C. Uses for crocodile oil and crocodile oil containing products. Available from: https://www. croccity.co.za/crocodile-products/\#croccream. Accessed on: 16 April 2019. 